\title{
Za kulisami wojny i pokoju (1914-1945). Z pamiętnikarskiej narracji polskiego dyplomaty i publicysty Jana Stanisława Łosia
}

\section{Abstrakt}

Celem artykułu jest zapoznanie czytelnika z barwną, pamiętnikarską opowieścią profesora historii starożytnej, Jana Stanisława Łosia, który przybliża odbiorcy kulisy obu wojen światowych i kruchego pokoju, wymagającego wielu zabiegów dyplomatycznych, ciągłego umacniania i stabilizowania. Autor w okresie międzywojennym znany był jako aktywny polityk obozu konserwatywnego i publicysta szeroko komentujący ówczesną scenę polityczną. Zaangażowanie polityczne, pochodzenie szlacheckie oraz odpowiednie wykształcenie sprawiły, że miał doskonałą możliwość oglądania zza kulis istotnych decyzji i wydarzeń wpływających na losy Polski i Europy. Znał osobiście wielu polityków krajowych i zagranicznych, których postaci przywołuje na kartach wspomnień. Jako znawca historii starożytnej potrafił ocenić mechanizmy działania władzy, jej sukcesy i porażki w kontekście dziejowego procesu historii. Pamiętnik powstał w latach siedemdziesiątych, czyli pod koniec życia autora, który podejmując się spisywania wspomnień, postanowił pozostawić potomnym świadectwo epoki dawno minionej, na temat której w okresie powojennym funkcjonowało wiele negatywnych mitów i stereotypów. Próbując wiernie oddać atmosferę panującą za kulisami wojny i pokoju, autor obala również stereotypy i mity pozytywne, potrafi krytycznie ocenić opisywaną rzeczywistość. Omawiana lektura spełnia założenia formalne dokumentu osobistego, nazywanego dziś przez badaczy również ego-dokumentem, i wpisuje się w wielowiekową tradycję polskiej memuarystyki.

Słowa kluczowe: Jan Stanisław Łoś, wojna, pokój, okres międzywojenny, polityka, wspomnienia, pamiętnik, ego-dokument.

Zachowanie pamięci o barwnym i jednocześnie dramatycznym czasie minionym - czasie pokoju zapamiętanym w kontekście wojny oraz czasie wojny ukazywanym w kontekście pokoju - wydaje się nadrzędną motywacją przyświecającą profesorowi historii starożytnej, Janowi Stanisławowi Łosiowi (1890-1974), który z początkiem lat siedemdziesiątych ubiegłego stulecia postanowił oddać się pasji spisywania wspomnień. Myli się jednak ten, kto sięgając po lekturę pamiętnika, zakłada, że znajdzie w nim opis przeszłości emerytowanego wykładowcy, z żalem i nostalgią 
spoglądającego w odległą historię, której siłą rzeczy musiał być świadkiem. Łoś jest świadomy czyhających na autora tekstu wspomnieniowego pułapek w postaci nadmiernego subiektywizmu, egzaltacji i moralizatorstwa. Raz po raz zastrzega się i postanowienie konsekwentnie realizuje - że nie chce „zabarwiać [...] wspomnień nutą banalnej starczej melancholii” (Łoś 2017: 311) ${ }^{1}$. Z upodobaniem opowiada zatem „pogodnie uśmiechnięte epizodziki osobistego przeżycia” pozbawione — jak kokieteryjnie stwierdza — „historycznego znaczenia” (Łoś 2017: 311). Do wielu wydarzeń historycznych - niejednokrotnie przełomowych dla historii Polski czy Europy - autor jednak nawiązuje, gdyż wielu z nich był nie tylko biernym obserwatorem, ale i aktywnym uczestnikiem.

Warto dodać, że całość pamiętnikarskiego dzieła Łosia wpisuje się w bogatą tradycję wielowiekowej już polskiej memuarystyki (Cieński 1981) i jednocześnie uzupełnia wciąż niezagospodarowaną przestrzeń w literaturze dokumentu osobistego uprawianego przez elitę intelektualną okresu międzywojennego, szczególnie elitę polityczną. Współczesny czytelnik miał już okazję zapoznać się ze wspomnieniami kilku wybitnych polityków tego okresu, między innymi Ignacego Daszyńskiego (1925-1926), Stanisława Głąbińskiego (1939), Michała Bobrzyńskiego (1957), Wincentego Witosa (1978), Henryka Józefskiego (1982-1983), Stanisława Grabskiego (1989) czy Stanisława Kozickiego (2009). Znamienne, że niektóre pamiętnikarskie dzieła w całości lub fragmentach ukazały się na rynku czytelniczym jeszcze przed drugą wojną światową. Później — jeśli autora nie można było zaadaptować do nowego systemu politycznego - mogły być opublikowane wyłącznie poza granicami Polski. Na ich druk w kraju należało czekać do okresu przemian politycznych, które nastąpiły dopiero pod koniec lat osiemdziesiątych ubiegłego wieku (Marszał, Wójtowicz 2017: 15). Z tej samej przyczyny przedwojenna aktywność zawodowa profesora Łosia przez długie lata powojenne również pozostawała w sferze tabu. Dlatego też czytelnik znający wyłącznie jego biografię naukową ${ }^{2}$ może być zaskoczony informacjami na temat pochodzenia autora wspomnień, jego szeroko zakrojonej działalności politycznej, publicystycznej i społecznej sprzed drugiej wojny światowej i kontaktów towarzyskich.

Celem niniejszego artykułu jest zatem przybliżenie czytelnikom wciąż jeszcze mało znanej postaci ówczesnego świata polskiej polityki, a przede wszystkim poka-

${ }^{1}$ Ten i pozostałe cytaty źródłowe pochodzą z tekstu wspomnieniowego zawartego w tomie S. Łosia (2017). Wspomnienia zostały opatrzone wstępem, którego niewielkie fragmenty znajdują odzwierciedlenie w niniejszym artykule. Należy nadmienić, że w 2012 roku decyzją syna autora - Marka Łosia - z całości wspomnień została wyłączona i opublikowana część zatytułowana Sprawa ukraińska. Zob. S. Łoś 2012.

2 Po drugiej wojnie światowej Łoś otrzymał posadę w Katolickim Uniwersytecie Lubelskim, od 1957 roku pracował jako docent, a od 1959 roku jako profesor nadzwyczajny tegoż uniwersytetu. W latach 1957-1959 był dziekanem Wydziału Nauk Humanistycznych KUL. W 1961 roku odszedł na emeryturę, kontynuując pracę naukową w domowym zaciszu. Jego główne publikacje to Sylwetki rzymskie (1958); Rzym na rozdrożu. Studium monograficzne o Katonie Starszym (1960) i Świat historyków starożytnych (1968). 
zanie, jak z jej pozakulisowej perspektywy wyglądał świat między dwoma wojnami, jakim mechanizmom był podporządkowany, przez jakich ludzi i wydarzenia był kreowany. W celu przedstawienia pełniejszego obrazu postaci hrabiego J.S. Łosia warto przywołać wybrane informacje z biogramu (Łoś 2012: 19-21) upublicznionego u schyłku PRL. Jego autorami były dorosłe już dzieci profesora, przypominające - na przekór niesprzyjającym okolicznościom - dokonania ojca. Odnotowane w nim fakty znajdują potwierdzenie w obszernym tekście pamiętnika.

Jan Stanisław Łoś pochodził z rodziny ziemiańskiej; urodził się we wschodnio-galicyjskiej wsi Czyszki koło Sambora (dziś należącej do państwa ukraińskiego, w czasie powstawania wspomnień - do ZSRR) jako syn Mariana Jana Andrzeja i Heleny Kunegundy z Kotarskich. Autor, wskazując w pamiętniku miejsce urodzenia, pozwoli sobie na zawoalowaną krytykę opresyjnego powojennego systemu, pisząc z charakterystyczną dla siebie swadą: „[...] obecny dowód osobisty podaje, że miejsce mojego urodzenia leży między Przemyślem a Władywostokiem. Dokładniejszego umiejscowienia go odmówiono mi” (Łoś 2017: 20). W domu rodzinnym zaszczepiono w nim obowiązek staranności, w tym staranności wykształcenia. Ukończył zatem z bardzo dobrym wynikiem szkołę średnią w Zakładzie Naukowo-Wychowawczym Ojców Jezuitów w Chyrowie, po czym z powodzeniem realizował studia na Wydziale Prawa i Nauk Politycznych Uniwersytetu Wiedeńskiego, gdzie w 1913 roku uzyskał doktorat praw. Władał kilkoma językami obcymi: najlepiej niemieckim i francuskim. Posługiwał się też angielskim z akcentem - jak autoironicznie dodaje - przemyskim, ubolewając, że nie jest to akcent oksfordzki, ale jednocześnie dziękując Opatrzności, że nie jest to najgorszy z możliwych wówczas akcentów, czyli londyński. Jako „syn Galicji Wschodniej” doskonale rozumiał w mowie i piśmie również język ukraiński czy — jak mawiali jego przodkowie język ruski. Rzeczywistość pokazała, że odpowiednia edukacja, „dobre” nazwisko rodowe i związane z nim kontakty oraz splot okoliczności pozwoliły mu zaistnieć na scenie politycznej okresu międzywojennego. Z pewnością nie była to rola pierwszoplanowa, czego Łoś miał pełną świadomość: „Prawda, że na niejedno miałem możność patrzeć nie z wyżyn bynajmniej, lecz jak gdyby zza kulis, a więc przeważnie z boku i przy różnej mocy i różnej barwie oświetlenia" (Łoś 2017: 3-4). Innym razem zaznaczał:

Nie dokonałem [...] żadnych czynów bohaterskich, nie osiągnąłem żadnych czołowych dostojeństw, nie wyrosłem na tytana myśli powtarzanej przez wieki, nie wskazałem ludzkości nowych dróg i celów [...]. Po prostu przeżyłem lata dzielące chwile mych urodzin do chwili mej śmierci i na tym poprzestałem. (Łoś 2017: 3)

Zacytowany fragment - jak i wiele mu podobnych „zdystansowanych” odautorskich stwierdzeń - nie może jednak przysłonić faktu, że świadomość własnych predyspozycji intelektualnych oraz silne poczucie patriotyzmu, połączone $\mathrm{z}$ ambicją polityczną nie pozwoliły młodemu hrabiemu na bierne przypatrywanie się wydarzeniom zmieniającym bieg polskiej historii międzywojennej. We wspomnieniach 
autor odnotowuje, że przedświt powstawania nowego państwa zastał go jeszcze w czasie pierwszej wojny światowej, gdy odbywał (od 1915 roku) służbę wojskową w armii austriackiej C.K. Generalnego Gubernatorstwa. W 1916 roku przeszedł do Komendantury Okręgu w Olkuszu, po czym objął stanowisko sekretarza Zarządu Cywilnego Generalnego Gubernatorstwa w Lublinie. Był obecny podczas tworzenia polskiej administracji na ziemiach Królestwa Polskiego. Poznał wówczas wielu znanych polityków polskich, między innymi Józefa Piłsudskiego i Ignacego Daszyńskiego. Pertraktował z władzami austriackimi i niemieckimi, w tym z Generalnym Gubernatorem, Hansem von Beselerem, w sprawie powstania Polski.

Największa aktywność polityczna Łosia przypadła na lata 1918-1931, gdy pracował w Ministerstwie Spraw Zagranicznych. Powierzano mu wykonywanie zadań specjalnych, nierzadko o charakterze poufnym. Priorytetem było dbanie o dobry wizerunek Polski zarówno w kraju, jak i poza jego granicami. Hrabia zajmował się wówczas przede wszystkim międzynarodowymi aspektami mniejszości ukraińskiej w II RP. Poszukując możliwości złagodzenia nastrojów antyukraińskich w Polsce po przegranych przez Ukraińców walkach niepodległościowych z lat 1918-1919, próbował docierać do różnych ukraińskich środowisk politycznych. Warto przypomnieć, że do 1923 roku, czyli do ostatecznej decyzji Rady Ambasadorów, którzy przyznali sporną dzielnicę tak zwanej Galicji Wschodniej państwu polskiemu, Ukraińcy realizowali politykę negacji wobec polskiego aparatu państwowego. Po 1923 roku strona polska coraz częściej reagowała akcjami pacyfikacyjno-odwetowymi, zmuszając Ukraińców do przyjęcia zachowawczych pozycji. Swój udział w spacyfikowaniu postaw rewolucyjnych miał też autor pamiętnika. Ponad wszystko stawiał polską rację stanu, której fundamentem było utrzymanie jedności terytorialnej młodego państwa, szczególnie do czasu wiążących rozstrzygnięć na arenie międzynarodowej. W obliczu ukraińskiego bojkotu polskiej administracji w Małopolsce Wschodniej i nasilających się tam akcji sabotażowych Łoś uznał z początkiem lat dwudziestych, że zastosowanie karnej akcji odwetowej w tamtym czasie jest jedynym wyjściem z sytuacji - wydawałoby się - bez wyjścia. Krótką wzmiankę na temat kontrowersyjnej decyzji w kontekście relacji polsko-ukraińskich znajdujemy w jego korespondencji służbowej (Łoś 2012: 126). Autor tłumaczył, że kara może być skuteczna tylko wówczas, gdy jest uzasadniona, dotkliwa i krótkotrwała. Sprzeciwiał się jednak długofalowej polityce siły, uznając, że największym orężem państwa powinna być konstruktywna współpraca i stworzenie mniejszości narodowej - notabene najliczniejszej, a na ziemiach rdzennych przewyższającej w swojej liczbie ludność polską - odpowiednich warunków rozwoju ekonomicznego, gospodarczego i kulturowego w ramach II RP. Jego pogląd polityczny na sprawę ukraińską zakotwiczony był w nurcie konserwatywnym i oscylował między ideą asymilacji państwowej a programem federalistycznym. W skrupulatnie pisanych raportach i opiniach przekonywał przełożonych, że kontynuowanie działań pacyfikacyjnych może mieć dalekosiężne negatywne skutki dla wzajemnych relacji polsko-ukraińskich. 
Okres pełnienia funkcji naczelnika Wydziału Północnego, a następnie Wydziału Ustrojów Międzynarodowych w MSZ łączył się z zawieraniem wielu znajomości z przedstawicielami ukraińskiej elity intelektualno-politycznej, szczególnie z kręgu konserwatywnego, skupionego wokół postaci lwowskiego metropolity cerkwi grekokatolickiej, Andrzeja Szeptyckiego, a z czasem także biskupa stanisławowskiego, Hryhorija Chomyszyna. Łoś bardzo doceniał też współpracę z byłymi uczestnikami armii Semena Petlury, przebywającymi w Polsce na uchodźctwie zgodnie z umową Piłsudski-Petlura. Efektem tej współpracy była wieloletnia przyjaźń z prof. Romanem Small-Stockim ${ }^{3}$. W przeciwieństwie do Ukraińców galicyjskich „petlurowcy” nie rościli sobie pretensji do terenów Galicji Wschodniej i zdecydowanie chętniej podejmowali współpracę z przedstawicielami władzy polskiej na wyznaczonych przez nich zasadach. Dobra znajomość zagadnienia ukraińskiego oraz w ogóle problemów mniejszości narodowych w II RP pozwoliła hrabiemu na aktywne uczestnictwo w dyskusji na ten temat na forum Ligii Narodów. W połowie lat dwudziestych Łoś pracował też na rzecz przyspieszenia uznania autokefalii Polskiej Cerkwi Prawosławnej przez Patriarchat w Konstantynopolu. Jego konstruktywne stanowisko wobec ukraińskich aspiracji niepodległościowych i „racjonalna” sympatia dla mniejszości ukraińskiej w Polsce sprawiły, że na tle innych polskich polityków - w większości reprezentujących podejście nacjonalistyczne do kwestii wschodnio-galicyjskiej - Łoś postrzegany był przez polityków ukraińskich obozu umiarkowanego jako rzecznik ich sprawy w II RP. Należy mu przypisać zabiegi na rzecz upodmiotowienia mniejszości ukraińskiej w toczonych wówczas dyskusjach politycznych. W swoich wypowiedziach publicystycznych hrabia konsekwentnie przypominał, że nie należy mówić o „problemie ukraińskim”, który trzeba zlikwidować, ale o „kwestii ukraińskiej”, która wymaga poszukiwania i wdrażania odpowiednich rozwiązań ${ }^{4}$. Dlatego też wiadomość o oddelegowaniu hrabiego do polskiego poselstwa w Londynie (pracował tam w latach 1926-1931 jako chargé d’affaires) spotkała się z kurtuazyjnymi gratulacjami ze strony działaczy ukraińskich, ale i nieukrywanym zatroskaniem o własne losy z powodu utraty opieki osoby życzliwie ustosunkowanej do Ukraińców. Dokumentują to słowa pochodzące z listu metropolity Szeptyckiego z 1930 roku:

Czcigodny Hrabio!

[...] nominacji do Londynu z serca gratuluję, ale przyznać muszę, odczuwam stratę Hrabiego... dla nas, dotąd wiedząc, iż Hrabia w Warszawie, mieliśmy tę uspokajającą myśl, że w danym wypadku można [w] Warszaw[wie] uciekać się do szerokiej inteligencji i serca Hrabiego — dziś tę pomoc tracimy [...]. (Archiwum Łosiów z Niemiec, Korespondencja St. Łosia z arcybiskupem A. Szeptyckim i biskupem H. Chomyszynem. 1925-1942, sygnatura 451, k. 12)

${ }^{3}$ Obszerna korespondencja potwierdzająca znajomości z elitą ukraińską międzywojnia znajduje się w Archiwum Państwowym w Lublinie w zbiorach rodziny Łosiów z Niemiec.

${ }^{4}$ Zob. m.in. prace O konstruktywna politykę ukrainska w Polsce (1932a: 82-113); O konstruktywna politykę na Rusi Czerwonej (1932b: 5-44); W sprawie uniwersytetu ukraińskiego (1933: 4-10); Problem gospodarczy Ziemi Czerwieńskiej (1938: 195-221). 
Tymczasem praca w dyplomacji była — jak można sądzić — zwieńczeniem aspiracji politycznych Łosia, okazała się tą formą aktywności zawodowej, która dała mu poczucie spełnienia i która była również doceniona przez bezpośrednich przełożonych. We wspomnieniach autor odnotuje: „Pamiętam, jaką przyjemność sprawiły mi słowa p. Konstantego Skirmunta, gdy żegnałem się z nim, opuszczając Londyn: "Osiągnął Pan wszystkie cele, dla których Pan przyjechał «" (Łoś 2017: 117).

W 1931 roku na fali zmian politycznych w II RP Łoś odszedł ze służby dyplomatycznej i osiadł w Niemcach (pow. lubartowski). Tutaj mógł w pełni oddać się swojej drugiej pasji - pracy pisarskiej, publicystycznej. Korzystając z dotychczasowego dyplomatycznego doświadczenia oraz wciąż żywych kontaktów, chętnie podejmował się rozlicznych działań politycznych i społecznych wagi państwowej. W latach 1938-1939 z powodzeniem prowadził rozmowy dotyczące ustalenia warunków powrotu do kraju z przymusowej emigracji premiera Wincentego Witosa. Piastował funkcję sekretarza Zarządu Polskich Kawalerów Maltańskich (1931-1936) oraz zasiadał w Radzie Lubelskiej Izby Rolnictwa (1933-1939). Jednocześnie przez cały okres lat trzydziestych oddawał się działaniom na rzecz porozumienia polsko-ukraińskiego. Jeszcze w 1932 roku rozpoczął współpracę z „Biuletynem Polsko-Ukraińskim", który był specjalnie powołaną przez władze polskie platformą wypowiedzi "porozumiewawczych”. Czasopismo wspierane było przez Ekspozyturę II Oddziału Sztabu Generalnego (od 1928 roku - Sztabu Głównego) Wojska Polskiego, czyli wywiadu, Ministerstwa Spraw Wewnętrznych i Ministerstwa Spraw Zagranicznych. Łoś publikował też w organie prasowym wileńskich konserwatystów - „Buncie Młodych” - i „Polityce”. Jego artykuły ukazywały się również na łamach innych konserwatywnych czasopism, między innymi „Dnia Polskiego”, „Naszej Przyszłości”, „Przeglądu Współczesnego”, a także pismach ukraińskich, na przykład „Nowej Zorii” i „Mecie”.

Hrabia nie poprzestawał jednak wyłącznie na naprawie stosunków polsko-ukraińskich. Potrafił nawiązywać dobre relacje także z przedstawicielami innych narodów. Miał poprawne kontakty z Niemcami, Austriakami, Anglikami, Amerykanami, Francuzami, Rosjanami, Czechami, Węgrami. W pamiętniku przekonuje, że zawsze starał się wznieść ponad żywe wśród Polaków negatywne mity i stereotypy, ale również obalał naiwne stereotypy pozytywne. Na narody patrzył przez pryzmat ich osiągnięć politycznych, gospodarczych, kulturowych, a nie postawy poszczególnych jednostek. Jednostki z kolei oceniał na podstawie ich czynów i zachowań, stroniąc od narodowych uogólnień. Z charakterystycznym dla siebie realizmem pisał: „Naród nie może się składać z samych bohaterów, mędrców, wynalazców i poetów. Muszą się w narodzie znaleźć także poliszynele, także wulgarni ludzie z ulicy [...]" (Łoś 2017: 439).

W tekście pamiętnikarskim wspomina, że takie „niepolskie”, „nieantyfobiczne” podejście do innych sprawiło, że w okresie międzywojennym przypisywano mu niejednokrotnie łatkę ukrainomanii czy germanofilstwa. Podczas trudnych zabie- 
gów formowania się zachodnich granic II RP Łoś nie uległ bowiem patriotycznemu hurraoptymizmowi, co ułatwiało mu trzeźwy ogląd sytuacji i konstruktywną ocenę działań dawnych zaborców oraz sprzymierzeńców. Wspominając przeszłość, na przykład w kontekście relacji polsko-niemieckich, pisał:

Nie należę do tego nazbyt licznego w Polsce zastępu ludzi, którzy pisząc o Niemcach, a przede wszystkim o Prusach, uważają za swój obowiązek i dowód patriotyzmu pisać o nich urągliwie i malować ich w jak najczarniejszych barwach, odsądzając od czci i wiary. Z całą stanowczością stwierdzam więc tutaj raz na zawsze, że ani do Niemców w ogóle, a w szczególności do Prusaków nie odczuwam żadnej nienawiści. Walczyłem z nimi w tym okresie mego długiego życia, a trwał on przez sporą ilość lat, konsekwentnie i czasami z powodzeniem, ale walczyłem tylko dlatego, że byli naszymi wrogami [...]. Szkodziłem im na zimno. Nie taję, że taka walka sprawiała mi przyjemność [...]. Nie znaczy to jednak, bym nie miał widzieć sympatycznych znamion niemieckiej kultury, sympatycznych zalet niemieckiego narodowego charakteru. (Łoś 2017: 525)

Taka postawa pozwoli autorowi w przyszłości odciąć się od powojennych antyniemieckich nastrojów, mimo że w czasie drugiej wojny światowej zarówno on, jak i jego rodzina doświadczyli hitlerowskich represji. W pamiętniku bez wątpliwości przytaczać będzie znamienny cytat z Konrada Wallenroda Adama Mickiewicza: „Niemce też ludzie”, a we fragmentach poświęconych czasom okupacji hitlerowskiej, podczas której został zmuszony do oddania części majątku jednostce wojsk hitlerowskich, czytelnik znajdzie nie tyle opis traumatycznych przeżyć wojennych, których nie brakowało w rodzinie Łosiów, ile przywołanie „drobnego osobistego przeżycia z czasów okupacji” (Łoś 2017: 550). Autor wspomnień wojnę przetrwał w rodzinnym majątku Niemce pod Lublinem. Majątek w części został zarekwirowany przez wojska niemieckie, a hrabia znalazł się na liście czternastu zakładników zabranych ze wsi. Odpowiadali oni życiem za całość wojsk tam kwaterujących. Hrabia figurował na liście jako numer „1” z rozkazem codziennego meldowania się w komendzie. W październiku 1944 roku na teren Lubelszczyzny wkroczyła Armia Czerwona. Jako przedstawiciel warstwy ziemiańskiej Łoś został zakładnikiem kolejnego okupanta. 18 października 1944 roku został aresztowany przez Urząd Bezpieczeństwa i uwięziony na zamku w Lublinie. Więzienie opuścił w maju 1945 roku. Od tego czasu swoją działalność zawodową ograniczył do pracy naukowej na Katolickim Uniwersytecie Lubelskim. Z pamiętnikarskiej narracji wynika, że jej autor miał wyjątkową umiejętność „chłodnej” oceny położenia, w którym się znalazł, dlatego też dokonując oglądu rzeczywistości - zarówno na bieżąco, jak i z dystansu, po wielu latach - potrafił z przekonaniem napisać:

Nie żałuję tego, com widział i przeżył, choć plon z mego posiewu - o ile o plonie w tym wypadku mówić można - poszedł w dużej mierze na marne, a to, co z niego ocalało, przypadło komu innemu. Powiem więcej, powiem, że jako starzec z przyjemnością wspominam te odległe czasy, które nie zawsze były przyjemne, a pisząc wspomnienia, oddaję maleńką usługę tym, co kiedyś tamte dzieje poznać zechcą. (Łoś 2017: 120) 
Przedstawione informacje biograficzne w pojałtańskim ładzie politycznym znane były tylko nielicznym badaczom historii ${ }^{5}$, przyjaciołom oraz — jak zostało wspomniane - rodzinie, która przez lata pozostawała jedynym depozytariuszem „dobrej pamięci” ziemiańskiej rodziny Łosiów. W okresie funkcjonowania PRL to przede wszystkim w jej posiadaniu znajdowały się liczne dokumenty osobiste i oficjalne w postaci korespondencji, sprawozdań, rękopisów i kopii wydawniczych wielu przedwojennych publikacji hrabiego czy wreszcie maszynopisu omawianego dzieła. Zgromadzony materiał archiwalny, oprócz pamiętnika, decyzją profesora Łosia po wielu latach przekazano do Archiwum Państwowego w Lublinie. Kilkutomowy tekst wspomnieniowy zaś pozostał pod opieką syna autora, Marka Łosia.

Wspomnienia przyciągają uwagę obfitością faktów historyczno-obyczajowych, śmiałością sądów i wreszcie zaskakują swoistą „dziarskością” oraz „młodzieńczością” narracji. Wyraźnie ujawnia się $\mathrm{w}$ nich zacięcie pisarskie Łosia, który jeszcze w II RP dał się poznać nie tylko jako wytrawny autor publikacji publicystycznych i naukowych, lecz także jako beletrysta, wydając w 1931 roku pod pseudonimem Henryk Mortęski książkę zatytułowaną Takiem jest życie. Już wtedy przyświecał mu cel ukazania nieoficjalnych meandrów ówczesnego życia. Jak wskazuje biogram, autorowi dobrze znane były kulisy polskiej sceny politycznej II RP, szczególnie lat dwudziestych, co w tekście wspomnień zaowocuje skrupulatnym zapisem wielu detali życia polityczno-społecznego tego okresu. Warto jednak podkreślić, że Łoś czuje odpowiedzialność za słowo i stroni od taniej sensacji, raz po raz zapewniając "przyszłego czytelnika”, że pisze po prostu tak, jak było, względnie jak mu się wówczas wydawało, że jest. Doskonale rozumie specyfikę wybranego gatunku osobistego czy też - by użyć terminu coraz częściej stosowanego przez badaczy - egodokumentu (Szulakiewicz 2013: 65). Zdaje sobie sprawę z pewnych jego ułomności, szczególnie związanych z przekazywaniem treści historycznych. Wie, że egodokument nie jest wolny od subiektywizmu, racjonalizacji, swoistego nad-pisania lub nie-dopisania faktów. Chcąc być jak najbliżej prawdy, stara się zatem uchwycić historię własnego życia i historię Polski, wpisaną w klamrę obu wojen światowych, z perspektywy młodego człowieka sprzed przeszło sześćdziesięciu lat oraz profesora historii, dawno wycofanego z obiegu. Stosując strategię świadectwa, co jest domeną każdego ego-dokumentu ${ }^{6}$, autor przede wszystkim korzysta $\mathrm{z}$ narzędzi, jakie daje mu wypowiedź wspomnieniowa lub pamiętnikarska. Swoje dzieło nazywa też wprost „pamiętnikiem” lub „wspomnieniami”. Własna historia wydaje się odgrywać w nim drugorzędną rolę. Autor nie koncentruje się specjalnie na sobie, własnych czynach, sukcesach czy porażkach. Nie zamierza przecież tworzyć autobiografii. Zdecydowanie daleki jest od propagowania własnej legendy:

${ }^{5}$ Por. m.in. Zwolski 1975. Kolejne prace pojawily się dopiero po okresie przemian. Zob. np. Zaszkilniak 1997: 431-455; 1996: 62-72; Trojanowska 1998: 71-84; 1999; Kusz 2010; Wójtowicz 2013: $16-22$.

${ }^{6}$ Zob. Buryła 2002: 239. Por. też Cieński 1992; 2002. 
Książek poświęconych „małej wojnie” [I wojnie światowej — S.W.] napisano już dziesiątki tysięcy; napisano też bez miary osobistych wspomnień. Nie usiłuję się wtłaczać pomiędzy tych marszałków i ministrów, pomiędzy potentatów i dygnitarzy wszystkich stopni. Nie odgrywam żadnej roli, nie mogę więc stawiać sobie pomnika [...]. (Łoś 2017: 120)

Czytelnik znajdzie zatem w tekście pamiętnika przede wszystkim uzupełnienie "patchworkowego"7 obrazu epoki międzywojennej, który zarówno utkany był z reprezentacyjnych fragmentów barwnych, pięknych i gładkich, jak i - co wielokrotnie dokumentuje Łoś - składały się na niego też części mało atrakcyjne, zgrzebne i szare. Motywem przewodnim będzie tutaj zjawisko wojny i pokoju.

W pamiętnikarskiej opowieści nader istotne jest zachowanie pamięci o dwudziestoletnim pokoju, na który przypadało istnienie wolnej Polski. Autor skrupulatnie ukazuje czytelnikowi drogę prowadzącą do wolności, której był naocznym świadkiem, a na niewielkim odcinku nawet inspiratorem. Warto dodać, że to po części dzięki niemu nie weszły w życie ustalenia pokoju brzeskiego (z $1918 \mathrm{roku}$ ), na mocy którego miało powstać państwo ukraińskie z włączeniem ziem uznawanych przez Polaków za ich własne, i to w przeddzień powstania II RP. Nie znaczy to bynajmniej, że młody pracownik Urzędu Generał-Gubernatora w Lublinie miał możliwość oficjalnego wpłynięcia na bieg wydarzeń. Z narracji wspomnieniowej wynika, że usłyszawszy pogłoski o możliwości realizacji niekorzystnych dla losów Polski rozwiązań, hrabia zachował trzeźwość umysłu i po prostu wykonał odpowiedni telefon, przekazując niepokojącą informację do wiadomości osób decyzyjnych po stronie polskiej. Innym razem, w 1926 roku, według wypracowanej przez Łosia koncepcji podczas rozmów w Locarno minister spraw zagranicznych Aleksander Skrzyński wprowadził II RP (w sytuacji wydawałoby się beznadziejnej) do Ligii Narodów, ubiegając Rzeszę Niemiecką i uspokajając państwa członkowskie. Opisywany czas był bowiem okresem bardzo kruchego pokoju na arenie międzynarodowej. Potrzebne było zatem stałe wzmacnianie go licznymi zabiegami dyplomatycznymi. Obfitował również w liczne konflikty wewnętrzne. Słowem-kluczem wydaje się tutaj słowo „walka”: walka różnych stronnictw politycznych o władzę, walka o uregulowanie i utrzymanie granic, walka z mniejszościami narodowymi itd. Atmosferę tego czasu po części oddaje wypowiedź Mileny Rudnyckiej - ukraińskiej działaczki politycznej i społecznej reprezentującej skrajne skrzydło największej legalnej partii politycznej w II RP - Ukraińskiego Zjednoczenia Narodowo Demokratycznego - UNDO. We wspomnieniach dotyczących relacji polsko-ukraińskich w Polsce na terenie Galicji Wschodniej pisała:

Ówczesna terminologia polityczna nie znała jeszcze określenia „zimna wojna”. Jednak termin ten oddaje najlepiej sytuację panującą na ukraińskim zachodzie w okresie między dwiema wojnami światowymi: na ukraińskich ziemiach zachodnich w przeciągu 20 lat panował stan permanentnej zimnej wojny ${ }^{8}$. (Rudnycka 1998: 350)

${ }^{7}$ Por. Społeczeństwo II RP. Opisując epokę, jej różnorodne społeczeństwo, autor artykułu używa określenia „polski patchwork”.

8 Tłumaczenie własne. 
Przed rzeczywistą wojną miały uchronić Polskę oraz Europę traktaty, porozumienia, układy, których Łoś jako dyplomata wielokrotnie był naocznym świadkiem, a jako publicysta - aktywnym komentatorem. We wspomnieniowych opisach stylu i ducha znanych mu wydarzeń autor przywołuje całą plejadę aktorów ówczesnej sceny politycznej - zarówno zagranicznej, jak i krajowej. Sporo miejsca poświęca poszczególnym przywódcom mocarstw europejskich odchodzących po pierwszej wojnie światowej do lamusa. Dużym jego zainteresowaniem cieszy się władca Austro-Węgier - Franciszek Józef, wszakże Łoś był przedstawicielem pokolenia, które jeszcze pamiętało świat „za cesarza”. Zatrzymując kadr wspomnień na jego postaci, autor nie podziela tak chętnie wypowiadanej po latach przez wielu ostrej krytyki wobec Franciszka Józefa, choć - jak zawsze - potrafi dostrzec zarówno zalety, jak i wady:

Rzecz szczególna, że cesarz Franciszek Józef zdawał sobie półświadomie sprawę z tego, że w chwilach rozstrzygnięć ciąży nad nim jakieś fatum, zmuszając go do dokonania wyboru zgubnego. Zwierzał się parokrotnie najbliższym, że „ma pecha” - nie miał do siebie zaufania, które jedynie pozwala pokonać przeciwności losu. Nie miał w sobie nic z kompleksów Ludwika XIV, który stojąc nad grobem wiedział, że "nie pozwoli wrogowi zbliżyć się do stolicy”. Pracowity i sumienny nie był obdarzony wyobraźnią ani polotem, oschły i porządnicki nie umiał oczarować jednostek, zdawał sobie z tego sprawę i z typowo wiedeńskim humorem mawiał nieraz o sobie, że „nadawałby się tylko na radcę dworu". (Łoś 2017: 515)

Łoś pokusi się również o zarysowanie portretu psychologicznego ostatniego władcy Austro-Węgier - Karola I Habsburga, pozwalając sobie na nazwanie go nieudolnym „biedaczyskiem”. Na kolejnych kartach przypomni też króla Edwarda II, odniesie się do Fryderyka Wilhelma II, kanclerza Ottona von Bismarcka, kanclerza Bernharda von Bülowa, opisze również postaci czeskich prezydentów: Tomaša Masaryka i Edvarda Beneša. Chętnie opowie o generałach i dowódcach spotkanych przypadkiem lub poznanych osobiście przy okazji pełnienia służby wojskowej, a następnie dyplomatycznej. Generałowi Hansowi von Beselerowi, którego dziełem miała być próba „ni mniej, ni więcej tylko powołania do nowego życia państwa polskiego, pogodzenie racji stanu pruskiej i polskiej" (Łoś 2017: 144), poświęca cały rozdział, argumentując:

[...] wydaje mi się [...], że postać gen. Beselera jest na tyle interesująca, że warto mu poświęcić maleńki, ale osobny rozdzialik moich wspomnień i spróbować ją naszkicować, jak, po z górą pół wieku, wygląda w mej pamięci. A widzę ją wyraźnie i mógłbym namalować portret generała gdybym miał jakikolwiek talent malarski. (Łoś 2017: 138)

Łoś z niewątpliwym talentem pisarskim wspomni postać Beselera jeszcze wielokrotnie w innych częściach wspomnień „w związku z jakąś sytuacją polityczną lub $\mathrm{z}$ jakimś etapem rozwoju tzw. sprawy polskiej w ostatnim dwuleciu »małej wojny światowej« [opisze - S.W.], jak wyglądała ta sprawa oglądana z okienka lubelskiego partykularza” (Łoś 2017: 138). Najważniejszą „sytuacją polityczną” dla autora pamiętnika będą zabiegi zmierzające do powstania Rzeczypospolitej. Znamienne, że fakt ten hrabia nie nazwie powołaniem, odrodzeniem czy utworzeniem państwa. Obalając nazbyt pozytywne wyobrażenia o wspomnianym czasie, prędzej powie 
o „wybuchu Polski”, który nie przez wszystkich i nie do końca był oczekiwany oraz uświadamiany. Konsekwentnie unikając hurrapatriotycznej egzaltacji, napisze:

Pierwsza wojna światowa przyniosła wreszcie koniunkturę, która automatycznie przyniosła Polsce byt państwowy. Zabrakło rozbiorców, przeciw polska koalicja pękła. Polacy niczym na taki wynik wojny wpłynąć nie mogli i nie wpłynęli. Że nie brakło zespołów, które sobie przypisywały miano i zasługi wskrzesicieli Polski, to zrozumiałe. W rzeczywistości Polacy ujęli losy ojczyzny w swe ręce dopiero po zawaleniu się mocarstw zaborczych. (Łoś 2017: 234)

Przypominając niełatwy proces powstawania polskich struktur wojskowych oraz całego aparatu państwa, Łoś kreśli sylwetki wielu aktorów rodzimej sceny politycznej. Nie brakuje wśród nich osoby Józefa Piłsudskiego, któremu autor nie odmawia należnych zasług, ale też potrafi racjonalnie ocenić jego sposób sprawowania władzy:

Wiemy, że za rządów marszałka Piłsudskiego skład gabinetów ministerialnych zmieniał się nie mniej często niż za tzw. sejmowładztwa. Ale były to zmiany czysto pozorne; im bardziej się coś w tych kręgach zmieniało, tym bardziej pozostawało wszystko na miejscu. Nie zmieniał się przecie marszałek (co nie znaczy, że się na starzał i nie opadał na siłach). Im bardziej był wszechwładny, tym większą sprawiało mu przyjemność przesuwanie lub wywracanie ministrów. Dziecko też lubi przesuwać i wywraca figurki na szachownicy. Marszałkowi chodziło o to, by żaden minister nie uroił sobie, że jest czymś lub że coś znaczy. „Z nicości Cię wziąłem i do nicości odsyłam”. To samo myślał Ludwik XIV. Zmiany gabinetów były to tylko „Zmiany warty”. (Łoś 2017: 237)

W podobnym tonie została utrzymana narracja, w której pamiętnikarz rozprawia się z tendencyjnym postrzeganiem innych znanych polskich polityków, stronnictw politycznych czy instytucji. Cały rozdział poświęca wspomnieniu o początkach i rozwoju polskiej dyplomacji międzywojennej oraz własnej służby zagranicznej. Czytamy:

Zaistniało państwo, trzeba było zaimprowizować organy, bez których państwo obejść się nie może. Zaimprowizowało się więc ex nihilo polską dyplomację. Albośmy to jacy tacy! [...] W każdej innej dziedzinie aparatury państwowej Polska odziedziczyła cokolwiek po państwach zaborczych; [...] Kadr dla stworzenia korpusu dyplomatycznego Polska po państwach zaborczych nie odziedziczyła. Zaimprowizowano go więc ex nihilo, jak najszybciej, natychmiast. Łatwiej znaleziono szefów niż personel. Skombinowano go z tego, co nawinęło się pod rękę, mocno inaczej niż powstało światło w pierwszym dniu stworzenia. To, co powstało, było kłębowiskiem przypominającym pierwotny chaos, w którym wirowały i zderzały się bezładnie atomy przyniesione przez wichry z wszelkich stron świata wiejące. Minęło wiele miesięcy zanim z tego kłębowiska poczęły się wyłaniać zręby zasługujące na nazwę korpusu dyplomatycznego. (Łoś 2017: 234-235)

Łoś nie może oprzeć się pokusie definiowania problemów i swoistego rozliczania błędów korpusu dyplomatycznego. Od MSZ — podobnie jak innych resortów państwowych - inteligencja wszystkich zaborów oczekiwała utworzenia odpowiedniej liczby posad, która gwarantowałaby jej „krzesła za biurkiem i wypłacane co pierwszego pobory" (Łoś 2017: 236). Realnym problemem nowych kadr była jednak słaba znajomość języków zachodnich oraz brak odpowiedniego doświadczenia. $\mathrm{Na}$ pierwszy plan wysuwały się ambicje i miraże. Do pracy w MSZ tłumnie zgłaszali się, a raczej - jak pisze Łoś - „wdzierali się drzwiami i oknami” urzędnicy, którzy „najczęściej przychodzili w charakterze drużynowych przedstawicieli poszczegól- 
nych stronnictw (a Bóg jeden wie, ile ich wtedy było), które chciały w każdym ministerstwie mieć »swoich ludzi«, by dzięki nim kontrolować poczynania rządu” (Łoś 2017: 236). Prawdziwą plagą zaś były jawnie toczące się walki poszczególnych frakcji zaopatrzonych w „szczekotliwe gazety i gazetki”, które zajadle zwalczały przeciwników. Ówczesna prasa polska - pomijając poważne organy prasowe, które jawnie wyrażały opinie bliskie danej części społeczeństwa i które mogłyby „wytrzymać porównanie z organami zachodnio-europejskimi” - uznana została przez autora wspomnień, za „drugą plagę”, wręcz „wrzód”, polskiego korpusu dyplomatycznego (Łoś 2017: 240). W jednym $\mathrm{z}$ fragmentów autor skomentuje: „[...] powietrze było pełne drukowanych wrzasków. Słuchając ich, a raczej czytając je, zazdrościłem cesarzom chińskim. Ci mieli do kierowania prasą bambusy” (Łoś 2017: 242).

Wobec braku odpowiedniego personelu MSZ nie było w stanie stworzyć dobrego biura prasowego, niezbędnego w tego typu jednostce. Kolejnym realnym problemem dyplomacji „powstałej z nicości”, który skutkował niekontrolowanymi decyzjami o zasięgu krajowym oraz zagranicznym, był brak wewnętrznej spójności i współpracy między poszczególnymi szczeblami urzędu centralnego oraz centralą i podległymi jej placówkami. Łoś pisze: „W takim stanie rzeczy rodziły się różne wyrastające nad głowy oficjalnych kierowników polityki zagranicznej wydarzenia, jak wyprawa kijowska albo »bunt « poczciwego generała Żeligowskiego i zajęcie przezeń Wilna” (Łoś 2017: 245).

Konsekwentnie unikając mitologizacji czasu minionego, autor zastrzega się jednak, że jego wspomnienie pozbawione jest „najmniejszego odcienia żółci czy wrogości” (Łoś 2017: 235). Wartością nadrzędną jest tutaj poszanowanie prawdy podczas wydobywania na światło dzienne polskich porażek, bolączek, ale i sukcesów okresu międzywojennego. Łoś ma pełną świadomość, że po drugiej wojnie światowej pamięć o historii II RP była mocno zdeformowana, więc stara się zakreślić obraz epoki znacznie wierniejszy niż ten, który wykrystalizował się w świadomości pokolenia dorastającego w czasach PRL, ponieważ: „Ma ono o tamtej epoce wyobrażenie wyniesione $\mathrm{z}$ podręczników szkolnych i z artykułów prasowych przepisywanych i powtarzanych przeważnie bezmyślnie, a bywa nazbyt, niestety, często... nieuczciwie" (Łoś 2017: 46).

Odtwarzając atmosferę dowojennej rzeczywistości, autor dba o zachowanie dobrej pamięci o politykach tak zwanego drugiego garnituru, którzy według niego mieli nieocenione zasługi dla polskiej polityki zagranicznej, niezależnie od tego „po jakiej się znaleźli stronie w ostatnich stadiach drugiej wojny światowej i po niej” (Łoś 2017: 237). Będą to

prof. Makowski, p. Szymon Runstein, prof. Leon Babiński, uczeni znawcy prawa międzynarodowego, wytrawni w ocenie, rzeczowi, nieusiłujący nigdy narzucać „swojej polityki”, a więc wolni od błędu, w który tylu naszych dyplomatów wpadło. Dalej pp. Kajetan Morawski, Tadeusz Jackowski, Mirosław Arciszewski, Juliusz Łukasiewicz, Józef Potocki, Edward Raczyński, Michał Potulicki, Michał Łubieński, Jan Wszelaki, Tadeusz Romer, Władysław Skrzyński, Tadeusz Hołówko [...]. (Łoś 2017: 237) 
Pamiętnikarz podkreśla jednocześnie, że poglądy i decyzje wymienionych dyplomatów nie zawsze były zgodne z jego stanowiskiem. Wszystkich łączyło jednak przekonanie, że każdy kieruje się „wyłącznie dobrem służby” (Łoś 2017: 238) oraz tym, co zdaniem autora wspomnień powinno być naczelną wartością i zasadą dyplomacji, czyli polską racją stanu. Decyzyjnych polityków stojących u steru polskiej polityki zagranicznej, prawdziwych mężów stanu, którzy w ideologiczno-politycznym chaosie międzywojnia potrafili sprecyzować, czym jest polska racja stanu oraz czym w ogóle jest Polska powstała z fragmentów ziem przez kilka stuleci należących do państw zaborczych, hrabia wymienia naprawdę niewielu. Przez wiele lat niepodzielny prym w kreowaniu polskiej polityki zagranicznej wiódł — jak wiadomo -Piłsudski. Łoś nie odmawia „wielkiemu Marszałkowi” niewątpliwych zasług na tym polu, choć wiemy, że potrafi też dostrzec wady jego polityki wewnętrznej oraz środowisk współpracy z nim. Według oceny hrabiego funkcjonujący w cieniu Marszałka ministrowie spraw zagranicznych nie wypracowali samodzielnych strategii. August Zaleski był - by użyć słów pamiętnikarza — „niczym innym, jak nieszkodliwym zawiadowcą spraw bieżących” (Łoś 2017: 267). Obejmował tekę ministerialną do momentu, gdy „Marszałek znalazł [jak sam to określił - S.Ł.] »odpowiedniejszego wykonawcę [...] rozkazów« w osobie pułkownika Becka” (Łoś 2017: 267). Ten po śmierci Piłsudskiego stał się faktycznym szefem polskiej dyplomacji jako najlepszy spadkobierca jego myśli politycznej. Postać ministra Becka nie cieszy się jednak zbyt dużą sympatią autora wspomnień. Wśród czołowych polityków zasługujących na dobre wspomnienie i szacunek hrabia wskazuje przede wszystkim takie osobistości, jak Maurycy Zamoyski i Konstanty Skirmunt. Docenia też erudycję, polor i kilka osiągnięć dyplomatycznych Aleksandra Skrzyńskiego, choć wytyka ministrowi słabość utrudniającą osiągnięcie większych sukcesów — „kompleks baletnicy” przejawiający się w „głodzie oklasków ze strony gawiedzi, tj. ówczesnego sejmu i ówczesnej prasy" (Łoś 2017: 238). Niestety, ta rozkrzyczana i mocno spolaryzowana gawiedź zazwyczaj miała decydujący głos w sprawach teoretycznie leżących w gestii MSZ. Przejawy podobnego kompleksu dostrzega też Łoś w postawie ministra Becka tuż przed wybuchem drugiej wojny światowej.

Osobne miejsce w pamięci autora - wręcz otoczone głęboką czcią - zajmuje z kolei Gabriel Narutowicz, „nie tyle jako minister, ale jako »człowiek bez trwogi i skazy«, a takich — dodawał Łoś - jest mało na świecie" (Łoś 2017: 238). Mimo kalejdoskopowo zmieniających się szefów polskiej dyplomacji - szczególnie w pierwszych latach funkcjonowania II RP — i regularnych „przeczesywan” resortu, polskiej służbie dyplomatycznej udało się w końcu wypracować pewną tradycję i przestrzegać jej godnie. Podsumowując stan polskiej polityki zagranicznej w kontekście klęski, jaką było wypowiedzenie Polsce wojny przez III Rzeszę, autor pisze: „Druga wojna światowa była, jak to do znudzenia powtarzam, trzęsieniem ziemi, kataklizmem wynikłym ze zderzenia sił tak wielkich, że żaden wysiłek państwa ubogiego i słabego jak ówczesna Polska, nie mógł go ani odwrócić, ani okiełznać" (Łoś 2017: 237). 
W kolejnych fragmentach Łoś stara się też wytłumaczyć czytelnikowi fenomen zaistnienia i funkcjonowania niektórych przywódców europejskich, którzy byli "dziećmi” nowych czasów, przesiąkniętych rozmaitymi odmianami doktryny nacjonalistycznej prowadzącej w praktyce do wojny. W pamiętniku musi się więc pojawić nazwisko Benita Mussoliniego a przede wszystkim Adolfa Hitlera. Wspominając niezwykłą karierę tego ostatniego, autor przypomni, że w życiu politycznym nie należy lekceważyć roli absurdu:

Uczucia i kompleksy narodów i rządów bywały nieraz osądzane przez historię jako absurdalne, ale dyplomacja musi pamiętać, że absurd (także i własny), jeżeli osiągnie pewien stopień natężenia czy pewien stopień temperatury, staje się siłą realną, z którą trzeba się liczyć; siłą tym większą, im bardziej jest absurdalny. Dyplomacja winna zatem skrzętnie notować wszelkie ich natężenie; nie wolno jej niczego bagatelizować. Nie wolno jej też niczego i nikogo kochać lub nienawidzić. Jedynym kierownikiem jej postępowania jest zmieniający się nieustannie stosunek sił własnych i obcych, nieustanne zastanawianie się nad tym, jaka zmiana w istniejącym stosunku sił może polepszyć pozycję własną, a jaka ją pogorszyć, a przede wszystkim jakie polepszenie pozycji własnej jest w istniejącej, w danej chwili proporcji sił osiągalne, jakimi też osiągalnymi sposobami można w istniejącej sytuacji uniknąć jej pogorszenia. (Łoś 2017: 248)

W rozdziale dotyczącym dyplomacji pamiętnikarz pozwala sobie na dydaktyczny, wręcz moralizatorski ton, którego zdecydowanie unika w pozostałych częściach tekstu. Tutaj bowiem rozprawia o kwestiach i doświadczeniach, z których nauka powinna zostać zapamiętana, aby przyszłe pokolenia mogły uniknąć dramatu wojny.

Przytoczone przykłady pokazują, że wspomnienie wojny w pamiętnikarskiej narracji Łosia sprzężone jest przede wszystkim z rozległymi opisami czasu pokoju, zabiegami - zwłaszcza pozakulisowymi - o jego podpisanie, przetrwanie, a czasem i zerwanie. Wojna, a dokładnie obie przeżyte przez autora wojny światowe oraz rozdzielający je pokój okazują się motywem przewodnim wspomnień. W pierwszej połowie XX wieku były to kategorie bardzo bliskie czasowo i niemożliwe było ich osobne ujęcie. W sensie dosłownym „wojna” występuje w tekście pamiętnika ponad sto razy. Częściej jednak jest przywoływana niż opisywana. Łoś nie odtwarza tragicznych scen wojennych, czytelnik nie znajdzie też opisów batalistycznych, choć do wielkich bitew i wodzów $z$ historii powszechnej hrabia nawiązuje przy okazji analizy sytuacji bieżącej lub poszukując dobrego porównania dla posunięć czy postawy polityków międzywojnia. Obraz wojny autor ogranicza do licznych aluzji i kontekstów. Wspomnienie o niej wpisuje w historię osobistą, uwikłaną w historię Polski i Europy pierwszej połowy XX wieku. Wojna jest zatem ukazana - tak jak pokój — od strony kulis. Autor koncentruje się na życiu politycznym, społecznym, gospodarczym, obyczajowym, rodzinnym. Jest to życie do wojny, przed wojną, przez wojnę, w czasie wojny, po wojnie. Czytelnik spotyka się przede wszystkim $\mathrm{z}$ anegdotycznymi - co ciekawe - niepozbawionymi pewnej dozy humoru scenkami wspomnieniowymi, przywołującymi autentyczne przeżycia autora i jego rodziny. Zmysł humoru i umiejętność zachowania pewnego dystansu do siebie i innych autor uznawał wszakże za "największe oręże”. Wydarzenia wielkie, przełomowe będą tutaj bardziej tłem dla opisów treści codziennego życia i relacji międzyludz- 
kich. Dlatego też wojna w pamiętnikarskiej narracji Łosia przybiera niekiedy oblicze konkretnych postaci historycznych, a także postaci zwyczajnych, które barwnie wypełniały mikrokosmos życia autora. W licznych komentarzach odautorskich Łoś zdecydowanie podkreśla bowiem chęć oddania - mówiąc słowami Łempickiego „konturów prawdy” (Szulakiewicz 2013: 73), przede wszystkim obrazu epoki bezpowrotnie minionej oraz ludzi i wydarzeń ją tworzących. Spogląda jednak na nią "okiem historyka”, ale — jak zastrzega — „nie uczonego profesora, lecz po prostu starego człowieka" (Łoś 2017: 509). Połączenie doświadczenia życiowego z naukowym pozwoliło $\mathrm{mu}, \mathrm{z}$ jednej strony, na stworzenie interesującej narracji pozbawionej maniery wykładu ex cathedra, $\mathrm{z}$ drugiej zaś na uchwycenie i - jeśli sytuacja tego wymagała - analizę oraz ocenę przedstawianego wydarzenia w kontekście dziejowego procesu historii. We wstępie czytamy:

Wspomnienia moje będą mówiły nie tyle o mej osobie, ile o epoce, a raczej epokach lub światach, w których mi przyszło żyć. Bo - i to jest najważniejsze - w latach, na które przypadło moje życie, świat się dwukrotnie zawalił i dwukrotnie na zawaliskach zawalonego świata poczyniło się plenić nowe życie zgoła od poprzedniego odmienne. (Łoś 2017: 4)

Podobne zdania o rzeczywistości zniszczonej, zawalonej, utraconej, która bezpowrotnie odeszła do przeszłości, spotkamy w tekście wielokrotnie. Zazwyczaj nie mają one wyraźnego posmaku żalu. Autor próbuje unikać taniego sentymentalizmu. Jednak w sytuacji, gdy bliska mu maska ironii lub autoironii nie wystarcza, ubiera swoje emocje „w zbyt poetyczne wyrażenie” (Łoś 2017: 10) i pisze:

Nie ma tej dzielnicy Polski, w której [...] „stała moja kołyska”. [...]. Nie ma warstwy społecznej, do której należałem. Wszystko to zapadło się w przeszłość niepowrotną, choć kalendarzowo zdałoby się bliską. Żadna przeszłość powrotną nie jest, ale moja jest niezrozumiała już dla pokolenia zrodzonego po roku 1914, a tym bardziej dla zrodzonego po roku 1938. Trzęsienia ziemi, jakim była pierwsza, a tym bardziej druga wojna światowa, pochłonęły tamtą epokę, jak wybuch Wezuwiusza pochłonął miasta Herculanum i Pompeje. Gawędzący o swych wspomnieniach należy do nielicznych przeżytków tej przysypanej wystygłym popiołem epoki. (Łoś 2017: 10)

Odniesienie do największych paroksyzmów w historii XX wieku, jakimi bezsprzecznie były obie wojny światowe, znajdujemy w wypowiedziach bezpośrednich, ale również wielokrotnie w warstwie „podskórnej” (Gilbert Durand) pamiętnikarskiego tekstu. Z kolei wyrażenia typu „zawalisko zawalonego świata” oraz „przysypana wystygłym popiołem epoka", przywołujące w wyobraźni obraz gruzowiska i zgliszczy, wydają się nawiązywać do zestawu symboliki zła Paula Ricoeura, w którym istotną rolę odgrywa kategoria zmazy, kary i winy. W myśl tej hermeneutyki „zło jest tutaj czymś zewnętrznym w stosunku do człowieka, od człowieka niezależnym i zarazem jest całkowicie zależnym od woli człowieka" (Dobosz 2001: 73). W takich też kontekstach zjawisko wojny znajduje swoje uzasadnienie we wspomnieniach Łosia. Jego narracja nie jest jednak pozbawiona optymizmu, wprost przeciwnie, przecież na zawaliskach „poczęło się plenić nowe życie”, mimo że „Z goła od poprzedniego odmienne” (Łoś 2017: 4). Owa odmienność rzeczywistości zasadniczo nie wywołuje specjalnego autorskiego sprzeciwu. Łosiowi udaje 
się przedstawić własne widzenie historii z odpowiednim emocjonalnym dystansem i jednocześnie uniknąć chęci odwetu - nie tak rzadko nęcącej twórców literatury osobistej, o czym przypomina w jednym z fragmentów:

Każdy prawie pamiętnikarz poczuwa się do obowiązku zapewnienia czytelników, że będzie pisał „sine ira et studio”, trzymając się kurczowo prawdy. Nie przeszkadza to, że celem bardzo wielu pamiętników jest wystawienie ich autorowi pomnika trwalszego od spiżu lub rozprawienie się z przeciwnikami, których nie mógł pokonać, albo też odparcie oskarżeń, na jakie w ciągu życia się naraził. [...] Natknąłem się w życiu na paru (ale naprawdę niewielką ilość) wrogów, którzy starali się mi szkodzić nie bardzo wiem dlaczego; patrzyłem na nich przeważnie humorystycznie, bo lubiłem się śmiać i wyznaję, bijąc się w piersi, lubiłem - może nadmiernie — ośmieszać. [...] Zresztą, jeżeli i miałem kiedyś wrogów czy niechętnych, dziś ich zdaje się już nie mam, bo wszystkich przeżyłem i wspominam ich bez cienia nienawiści. (Łoś 2017: 4-5)

Wspomnieniowa historia poświęcona jest zatem życiu, w którym istotną cezurą jest wojna. Wszakże przestrzeń, również przestrzeń życia — zgodnie z teorią Toporowa - istnieje, o ile ma ograniczenia. Potwierdzenie tego znajdziemy już w nazwach poszczególnych rozdziałów, które odnoszą się do ważnych cezur historycznych: Okres galicyjski przed rokiem 1914, Rok 1918. Traktat brzeski, Dyplomacja polska w okresie międzywojennym i moja służba zagraniczna, Wspomnienie z okupacji.

Wobec obu wojen Łoś stosuje własną gradację. Pierwszą wojnę światową nazywa - co zostało podkreślone w jednym z cytowanych fragmentów - „małą”. Przyniosła bowiem zmiany, które - owszem — z punktu widzenia osobistych doświadczeń autora czy poszczególnych jednostek były istotne, ale w odczuciu ogółu — szczególnie w kontekście późniejszych wydarzeń - nie były na tyle trwałe, aby mogły zapisać się wyraźnie w pamięci potomnych:

Ta pierwsza wojna niczego nie rozstrzygnęła. Pozostawiła nieco gruzów, nie zostawiła czasu na odbudowę. Pokolenia, które po nas przyjdą, mogą słusznie mniemać, że ludzie „pierwszej wojny” trudzili się i krwawili nadaremno, usiłując po omacku schwytać zjawy nieżywotne i wręcz nietreściwe. [...] nadwyrężyła trochę ruder, które i tak pod własnym ciężarem same by się zawaliły. Pokolenie pierwszej wojny zasługiwałoby w oczach potomnych na nieco współczucia tych nielicznych, którzy nie bacząc na brak wyników, chcą pamiętać o trudach i cierpieniach, jakie przypadły w udziale ludziom tamtych czasów. Taką nagrodę przewidywał dla nich Mickiewicz, gdy mówił, że dopiero w dniu ostatecznego tryumfu synowie i wnuki ,zapłaczą nad ojców losami i wówczas łza ta lica ich nie splami”. (Łoś 2017, 119-120)

Według autora „jedyną wojną” zasługującą na miano „wielkiej” była druga wojna światowa, ponieważ tylko ona dała „wyniki robiące wrażenie trwałych” (Łoś 2017: 119). Przed nią hrabia czuje prawdziwy respekt, pewien rodzaj szacunku graniczący ze swoistym zachwytem, który towarzyszy nie tyle naocznemu świadkowi, ile znawcy historii. Nie rezygnując z porównania obu wojen, autor realistycznie stwierdza:

Trzęsienie ziemi, jakim była druga wojna światowa, przyniosła światu tyle zmian w każdej dziedzinie życia jednostek i narodów, że przebieg pierwszej wojny i związane z nim nastroje, nadzieje, osiągnięcia i złudzenia wydają się bardziej niezrozumiałe, dalekie i obce niż dzieje starożytnego Egiptu. Ludzie urodzeni w roku 1914 dziś stoją u progu starości, dzieci ich przyszły na świat w ciągu drugiej wojny lub już po jej zakończeniu i nie pamiętają, jak wyglądał świat „za cesarza”. (Łoś 2017: 119) 
Łoś, podejmując się spisywania wspomnień, próbuje ocalić od zapomnienia obraz tych dwóch dobrze mu znanych przedwojennych światów. Pisanie pamiętnika nie ma jednak dla niego formy terapeutycznej, oczyszczającej pamięć z traumatycznych przeżyć wojennych. Autor - co wielokrotnie zauważono - odcina się od emocji, szczególnie negatywnych, z satysfakcją podkreślając, że nigdy nie uległ ogólnonarodowej manii pookupacyjnej nienawiści. Podobnie nie pozwala sobie na negatywny komentarz dotyczący nowego ładu politycznego po drugiej wojnie światowej. A przecież jej wynik, zmieniając oblicze geopolityczne Europy Środkowo-Wschodniej, zmienił również bieg życia przedwojennych elit politycznych i intelektualnych. Znana i zdefiniowana dotychczas przez Łosia rzeczywistość również została brutalnie zastąpiona złowrogą i nieprzewidywalną. W czasie powstawania pamiętnika - na początku lat siedemdziesiątych XX wieku — wydawała się jednak na tyle trwała, że autor zakładał, czy raczej oczekiwał, mając na względzie troskę o losy rodziny, że jego wspomnienia zostaną upublicznione dopiero z początkiem 2000 roku. Pierwsze prace redakcyjne zostały jednak rozpoczęte po ponad 40 latach od ich napisania. Całość wspomnień do rąk czytelników trafiła pod koniec 2017 roku, u progu stulecia niepodległości Polski, co z pewnością przydało wydarzeniu wydawniczemu dodatkowego, symbolicznego wymiaru. Należy się spodziewać, że w dorobku memuarystyki polskiej uprawianej przez elitę polityczną międzywojnia wspomnienia Jana Stanisława Łosia zajmą szczególne miejsce. Autor, ukazując kulisy wojny i pokoju, nie tyle ocala od zapomnienia barwną historię własnego życia, ile uzupełnia białe plamy w historii Polski, obalając jednocześnie wciąż żywe w świadomości rodaków - zarówno negatywne, jak i pozytywne mity i stereotypy odnoszące się do opisywanego okresu.

\section{Bibliografia}

\section{Źródła}

Łoś S. (1932a): O konstruktywna politykę ukraińską w Polsce, „Nasza Przyszłość 21, s. 82-113.

Łoś S. (1932b): O konstruktywną politykę na Rusi Czerwonej, Warszawa.

Łoś S. (1933): W sprawie uniwersytetu ukraińskiego, „Biuletyn Polsko-Ukraiński” 3 (5), s. 4-10.

Łoś S. (1938): Problem gospodarczy Ziemi Czerwieńskiej, [w:] A. Bocheński,

Łoś S. (2012): Sprawa ukraińska we wspomnieniach, korespondencji i publicystyce: wybór pism, wyb., red. nauk., wstęp M. Marszał, S. Wójtowicz, posłowie M. Łoś, Kraków.

Łoś S. (2017): „Świat się w mych oczach dwukrotnie zawalił..."Wspomnienia dyplomaty, red. nauk., wstęp M. Marszał, S. Wójtowicz, przedsłowie M. Łoś, Kraków.

Łoś S., Bączkowski W. (1938): Problem polsko-ukraiński w Ziemi Czerwieńskiej, Warszawa, s. 195-221. 


\section{Literatura}

Bobrzyński M. (1957): Z moich pamiętników, Wrocław.

Buryła S. (2002): „Autobiograficzny trójkąt: Świadectwo, wyznanie i wyzwanie”, Małgorzata Czermińska, red. nauk. Ryszard Nycz, Kraków 2000 [rec.], „Pamiętnik Literacki” 93, nr 2, s. 237-242.

Cieński A. (1981): Pamiętniki polskie XVIII wieku, Wrocław.

Cieński A. (1992): Pamiętniki i autobiografie światowe, Wrocław.

Cieński A. (2002): Z dziejów pamiętników w Polsce, Opole.

Daszyński I. (1925-1926): Pamiętniki, t. 1-2, Kraków.

Głąbiński S. (1939): Wspomnienia polityczne, Pelplin.

Grabski S. (1989): Pamiętnik, t. 1-2, Warszawa.

Józefski H. (1982-1983): Zamiast pamiętnika, „Zeszyty Historyczne” z. 59, 60, 63.

Kozicki S. (2009): Pamiętnik 1876-1939, Słupsk.

Kusz P. (2010): Jan Stanisław Łoś wobec kwestii ukraińskiej (1918-1939). Analiza myśli polityczno-spoŁecznej, Lublin.

Marszał M., Wójtowicz S. (2017): „Wspomnienia” Jana Stanisława Łosia jako źródło historii okresu międzywojennego, [w:] „Świat się w mych oczach dwukrotnie zawalit...” Wspomnienia dyplomaty, red. nauk., wstęp M. Marszał, S. Wójtowicz, przedsłowie M. Łoś, Kraków, s. IX-XXVIII.

Mędrzecki W.: Społeczeństwo Drugiej Rzeczpospolitej, http://www.dwudziestolecie.muzhp.pl/index. php?dzial=latadwudzieste3.

Rudnyc'ka M., Statti, lysty, dokumenty, red. M. Bohaczews'ka-Chomjak, M. Djadjuk, J. Pełens'kyj, L'viv 1998.

Szulakiewicz W. (2013): Ego-dokumenty i ich znaczenie w badaniach naukowych, https://repozytorium. umk.pl/bitstream/handle/item/1531/PBE.2013.006,Szulakiewicz.pdf.

Trojanowska M. (1998): Archiwum Łosiów z Niemiec i jego znaczenie dla badań polskiej dyplomacji w okresie międzywojennym, „Miscellanea Historico-Archivistica” 9, s. 71-84.

Trojanowska M. (1999): Materiały do tzw. Kwestii ukraińskiej w Drugiej Rzeczypospolitej w spuściźnie Jana Stanisława Łosia, „Biuletyn Ukrainoznawczy” z. 5, s. 109-122.

Witos W. (1978): Moje wspomnienia, Warszawa.

Wójtowicz S. (2013): Bohaterowie drugiego planu polsko-ukraińskiego dialogu politycznego w okresie międzywojennym: $z$ korespondencji prywatnej polskiego dyplomaty hr. St. Losia $z$ ukrainskim duchownym prałatem Tytusem Wojnarowskim, [w:] I. Kocan (red.), Aktual'ni pytannia reformuvannia pravovoji systemy Ukrajiny: zbirnyk naukovych statej za materiałami X Miżnarodnoji naukovo-praktycznoji konferencji, Luc'k, s. 16-22.

Zaszkilniak L. (1996): Ukrajins'ko-pols'ke porozuminnia 1935 r. (za materiałami archiwu J.S. Łosia), „Probłemy słowianoznawstwa. Miżnarodnyj naukowyj zbirnyk” nr 48, s. 62-72.

Zaszkilniak L. (1997): Heneza i naslidky ukrains'ko-pols'koji normalizacji 1935 r., [w:] Z. Karpus, W. Rezmer, E. Wiszka (red.), Polska i Ukraina. Sojusz 1920 roku i jego następstwa, Toruń, s. 431-455. Zwolski E. (1975): Sp. prof. dr Jan Stanisław Łoś, „Biuletyn Informacyjny KUL” nr 1 (7).

\section{Archiwalia}

Archiwum Łosiów z Niemiec, Korespondencja St. Łosia z arcybiskupem A. Szeptyckim i biskupem H. Chomyszynem. 1925-1942, sygnatura 451, k. 12. 


\section{Behind the scenes of war and peace (1914-1945). From the narrative diary of Polish diplomat and publicist Jan Stanislaw Los}

\section{Summary}

The aim of the article is to familiarize the reader with a colorful memoir of Jan Stanislaw Los, a professor of ancient history who takes the reader behind the scenes of both world wars and fragile peace. The peace that requires many diplomatic efforts, constant strengthening and stabilization. In the interwar period, the author was known as an active politician of the conservative party and a publicist who commented a lot on the political scene of that time. Political commitment, noble descent and appropriate education gave him an excellent ability to witness important decisions that were made as well as events which affected the fate of Poland and Europe over the period indicated above. He knew personally many local and foreign politicians whose characters are recalled on the pages of memories. As an expert in ancient history, he was able to appraise the mechanisms of power, its successes and failures in the context of historical process. Memories arose in the 1970s, i.e. at the end of the author's life. By writing down the memories he decided to leave the posterity of a long-gone era, the era about which there were many negative myths and stereotypes in the post-war period. Trying to correctly reflect the atmosphere prevailing behind the scenes of war and peace, the author also disproves positive stereotypes and myths, can critically evaluate the discussed reality. The reading in question fulfills the form of a personal document, also called the ego-document, and forms the part of the centuries-old tradition of Polish memoiristics.

Keywords: Jan Stanislaw Los, war, peace, interwar period, politics, memories, diary, ego-document. 